Chirurgia (2020) 115: 726-734

No. 6, November - December Copyright@ Celsius

http://dx.doi.org/10.21614/chirurgia.115.6.726

\title{
Minimal Access Surgery for the Treatment of Gastric Gastrointestinal Stromal Tumours - A Single Centre Experience
}

\author{
Oana Stanciulea1*, Mihnea-Ioan Ionescu², Diana Blanita', Monica Lacatus', Cristian Gheorghe², Catalin Vasilescu' \\ "Dan Setlacec" Centre of General Surgery and Liver Transplantation, Fundeni Clinical Institute, Bucharest, Romania \\ ${ }^{2}$ Liver Unit, Queen Elizabeth Hospital Birmingham, University Hospitals Birmingham NHS Foundation Trust, United Kingdom \\ ${ }^{3}$ Centre of Gastroenterology and Hepatology, Fundeni Clinical Institute, Bucharest, Romania
}

*Corresponding author:

Oana Stanciulea, MD

"Dan Setlacec" Centre of General Surgery and Liver Transplantation Fundeni Clinical Institute

Fundeni Street 258, Bucharest, Romania E-mail: oanastanciulea@yahoo.com

\section{Rezumat}

Chirurgia minimal invazivă în tratamentul tumorilor stromale gastrointestinale (GIST) cu localizare gastrică - experiența unui singur centru

Introducere: În ultimele decenii tehnicile de chirugie laparoscopicã au fost adoptate din ce în ce mai mult în chirurgia generalã. Principalele dezavantaje tehnice ale laparoscopiei sunt legate de instrumente, de lipsa confortului ergonomic pentru chirurg şi se asociazã cu o curbã de învãțare lungã. Chirugia roboticã depãşeşte cele mai multe din limitele laparoscopiei şi are potențialul de a lãrgi indicațile chirurgiei minimal invazive.

Material şi Metodã: În perioada ianuarie 2002 - octombrie 2018 $\mathrm{s}$-au efectuat 25 de intervenții prin abord minimal invaziv pentru tumori stromale gastrointestinale cu localizare gastricã. Au fost analizate retrospectiv datele demografice, simptomatologia, localizarea şi dimensiunea tumorii, tipul de intervenție chirurgicalã efectuat, pierderea de sânge intraoperatorie, timpul operator şi durata spitalizãrii, rezultatele de anatomie patologicã precum şi incidența complicațiilor postoperatorii.

Rezultate: Vârsta medie a pacienților a fost 58 ani. Majoritatea leziunilor au fost localizate la nivelul marii curburi gastrice (7) şi la nivelul porțiunii distale a stomacului sau la nivelul antrului gastric (7). La 20 de pacienți s-a efectuat o intervenție prin abord laparoscopic şi la 5 pacienți prin abord robotic. Intervențiile efectuate prin abord laparoscopic au fost: în 4 cazuri bulbantrectomie şi în 16 cazuri rezecții parcelare gastrice. În cazurile efectuate prin abord robotic s-au practicat rezecții parcelare gastrice. Din 
intervențiile chirurgicale efectuate prin abord laparoscopic, un caz a fost convertit la abord clasic datoritã aderențelor de la o interventie clasicã în antecedente. Timpul operator mediu a fost 130 min. Dimensiunea medie a tumorii a fost $3,8 \mathrm{~cm}$. Nu au fost complicații postoperatorii cu excepția unui singur caz care a necesitat reintervenție pentru sângerare postoperatorie.

Concluzii: Chirurgia minimal invazivã în tumorile stromale gastrointestinale cu localizare gastricã este sigurã, fezabilã şi ascociatã cu morbiditate scãzutã. Abordul minimal invaziv ar trebui sã fie prima opțiune în cazul pacienților cu tumori de dimensiuni mici şi cu localizare favorabilã. Singurul factor care limiteazã în prezent folosirea pe scarã largã a acestui tip de abord este lipsa de experiențã în chirurgia minimal invazivã.

Cuvinte cheie: tumori stromale gastrointestinale, gastrectomie laparoscopicã, rezecție parcelarã gastricã, chirurgie roboticã

\begin{abstract}
Introduction: Laparoscopic techniques have been increasingly adopted in the field of General Surgery in the last decades. The main disadvantages of laparoscopy are related to limited degrees of freedom of instruments and poor ergonomics, which are associated with a steep learning curve. Robotic surgery overcomes most of the technical limitations of laparoscopic surgery and has the potential to expand the indications of minimal access surgery (MAS) in procedures that are difficult to perform using laparoscopy.

Methods:Patients who underwent MAS resections of gastric gastrointestinal stromal tumours (GIST) between January 2002 and October 2018 in a single Surgical Department were retrospectively analysed. Demographic data as well as the following characteristics were recorded for each patient: age, sex, symptoms, tumour location and size, type of surgical procedure, intraoperative blood loss, operative time, length of hospital stay, histopathological assessment of resection margins, and incidence of perioperative complications.

Results: The mean patient age was 58 (range, 27-81 years). Most lesions were found on the great curvature (7) and in the distal stomach or antrum (7), respectively. Twenty patients underwent laparoscopic resection, while five patients had robotic resection of gastric GISTs. Surgical laparoscopic treatment consisted of antrectomy $(n=4)$ and wedge gastrectomy $(n=16)$. In all robotic cases a wedge gastrectomy was performed. One patient was converted to open surgery due to adhesions from previous operation. The mean operative time was 130 minutes (range, 70-210 minutes). The mean tumour size was $3.8 \mathrm{~cm}$ (range, $2-7 \mathrm{~cm}$ ). There were no complications except one case that required reoperation for postoperative bleeding. There were no mortalities.

Conclusion: The MAS approach of gastric GISTs is safe and effective and it is associated with low morbidity. Therefore, it should constitute the first option in patients with small tumours and favourable locations. The only limiting factor for the widespread use of MAS resections for gastric GISTs is surgeon expertise in this challenging technique.
\end{abstract}

Key words: gastric gastrointestinal stromal tumour, laparoscopic gastrectomy, wedge resection, robotic surgery

\section{Introduction}

Gastrointestinal stromal tumours are the most common mesenchymal tumour located in the gastrointestinal tract. The most common site (in over $50 \%$ of the cases) is the stomach, followed by small bowel, large bowel and oesophagus $(1,2)$. The data from literature reports incidences between 10 and 15 cases of GISTs per million. The reported 
age ranges from 10 to 100 years, with a median age reported to be in the mid-60s for most studies. The gender distribution shows an almost equal distribution between males and females (3).

The most common symptoms of GIST include gastrointestinal bleeding and anaemia, early satiety, abdominal distension and pain due to tumour compression (4). In almost $20 \%$ of cases gastric GISTs are asymptomatic, and are diagnosed during upper endoscopy, CT or surgical procedures. Computed tomography and EUS-guided FNA are the diagnostic modalities of choice. A potential diagnosis of gastric GIST is confirmed immunohistochemically using anti-CD117 (c-kit) antibodies, since almost all GISTs (c. 95\%) are c-kit positive (5).

Criteria for differentiating benign from malignant gastric GISTs have been discussed for several years. The most reliable prognostic indicators are size and mitotic index. It is believed that indicating a risk level of GIST (low, intermediate, or high) is more appropriate than definitively labelling the tumour as benign or malignant. The most important cut-offs as indicators of aggressive clinical behaviour were tumour size of $5 \mathrm{~cm}$ and 5 mitoses/50 HPF $(5,6)$.

The treatment of GISTs is complete surgical resection if it is resectable. GISTs rarely metastasize to lymph node and therefore regional lymph node dissection is generally not needed. In addition, organsparing resection wedge resection is also appropriate from an oncological standpoint. Wide resection margins are not mandatory because submucosal lymphatic spread does not occur $(7,8)$. Most tumours, especially small tumours in a favourable location, can be easily approached by laparoscopy due to lower lever of complexity of the procedure (wedge resection). Despite its advantages, the technical limitations of conventional laparoscopy in terms of visualization and limited manoeuvrability of the instruments have relegated this method to a currently low adoption rate in gastric pathology. When a gastric resection is needed, and/or in cases of challenging locations, the significant improvements offered by robotic surgery could translate into an easier minimally invasive procedure $(9,10)$.

In this study, we sought to report our experience with laparoscopic as well as robotic gastric resections for GISTs.

\section{Methods}

Data from 25 consecutive patients who underwent MAS gastric resections performed for gastric GISTs between January 2002 and October 2018 at Fundeni Clinical Institute, "Dan Setlacec" Centre of General Surgery and Liver Transplant, Bucharest were retrospectively analysed from a prospectively maintained electronic database.

In the same period, another 90 cases of gastric resections for GISTs were performed via an open approach. The only selection criterion for minimally invasive approach was the surgeon's expertise in MAS techniques, as the latter is the only well established limiting factor in terms of employing this method in the surgical treatment of small gastric GISTs on a large scale. Previous abdominal surgery was not a contraindication to attempting the MAS approach. Our Department's protocol employs an initial exploratory laparoscopy in order to assess suitability to continuing with the MAS method or converting to open surgery. Only patients with a final pathological diagnosis of gastric GIST were included in the present study.

After institutional review board approval, medical records were reviewed for demographic data, symptoms, diagnostic modality, tumour location in the stomach, previous operations, surgical treatment (laparoscopic/robotic and the type of resection), operative time, conversion to open procedure, complications, length of stay in the hospital and histopathologic findings.

Preoperative upper digestive endoscopy was employed in all cases and all tumors with a diameter $<2-3 \mathrm{~cm}$ were marked with tattoo.

The operative technique involved placement of 3 to 5 laparoscopic ports. The camera port was placed just above the umbilicus. 
Most lesions were resected using a wedge technique facilitated by an endoscopic linear stapling device. Up to 3 loads were necessary. Gastric GISTs with predominant intraluminal involvement that were located on the posterior aspect of the stomach (Fig. l) were removed via a transgastric approach that involved an anterior gastrotomy (Fig. 2). At the end of the procedure the anterior gastrotomy was closed using an endoscopic stapler or absorbable running sutures (Fig. 3). In the robotic approach this step is significantly facilitated, especially in unfavourable anatomical locations.

3 lesions located near the gastroesophageal junction or the antrum were carefully sutured in order to avoid luminal narrowing. All three of these cases were approached robotically rather than laparoscopically, given the added technical advantage the former technique offers over the latter in terms of ease of manual suturing and crucially, avoiding potential luminal narrowing. Specimens were removed within a specimen retrieval bag. In four cases a laparoscopic-assisted antrectomy was necessary. After laparoscopic resection a side-to end gastroduodenostomy (on the posterior gastric) wall was performed using a circular stapler, via a $5 \mathrm{~cm}$ midline incision that was used for the specimen extraction (Fig. 4). One more linear stapler is required to close the gastric opening.

\section{Results}

The mean patient age was 58 (age range, 27-81 years). There were 8 males (32\%) and 17 $(68 \%)$ females. Five patients $(20 \%)$ were asymptomatic, and were incidentally diagnosed with GIST on routine image exams. Symptomatic patients were investigated for: pain $(n=11$; $44 \%)$, gastrointestinal tract bleeding $(n=6$; $24 \%)$. gastroesophageal reflux disease $(n=1$; $4 \%$ ), and dysphagia in 1 patient (4\%). All patients underwent an upper GI endoscopy.

Preoperative endoscopic tattooing of the tumour is not routinely performed in our service, but it can be useful in cases where the size of the mass is very small. In our series in

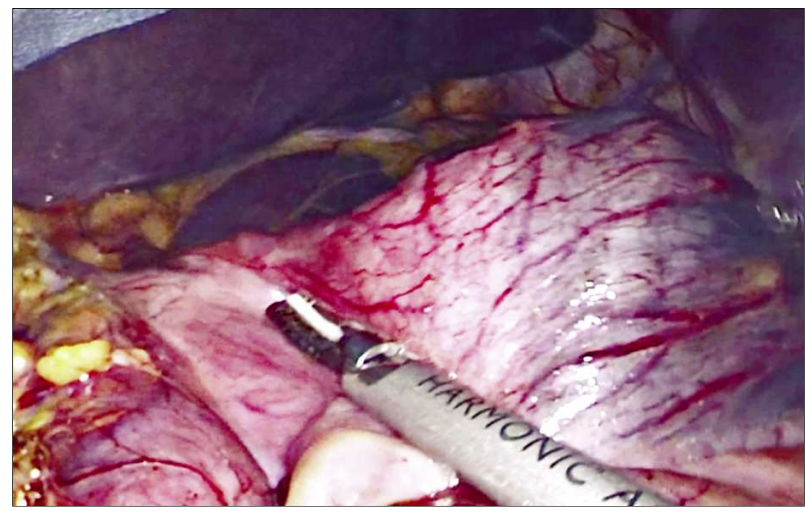

Figure 1. Intraoperative aspect of a gastric GIST located on the posterior aspect of the stomach

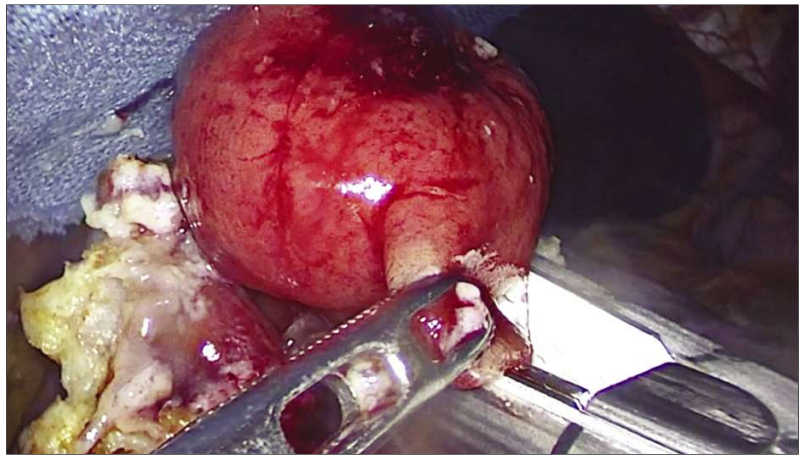

Figure 2. After the anterior gastrotomy is performed, the tumour is retracted ventrally into the gastrotomy and a stapler is placed inside the stomach, under the tumour

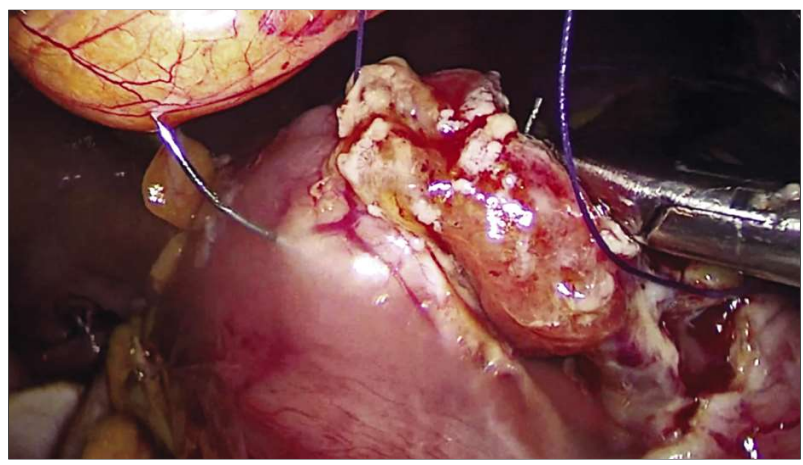

Figure 3. The aterior gastrotomy is closed using absorbable running sutures

patients 4 tumors tattooing was performed preoperatively. The imagistic modality employed most often in order to characterize the tumour before surgery was CT scan (Fig. 5). Of the 25 patients in our series, 19 underwent CT scan. 


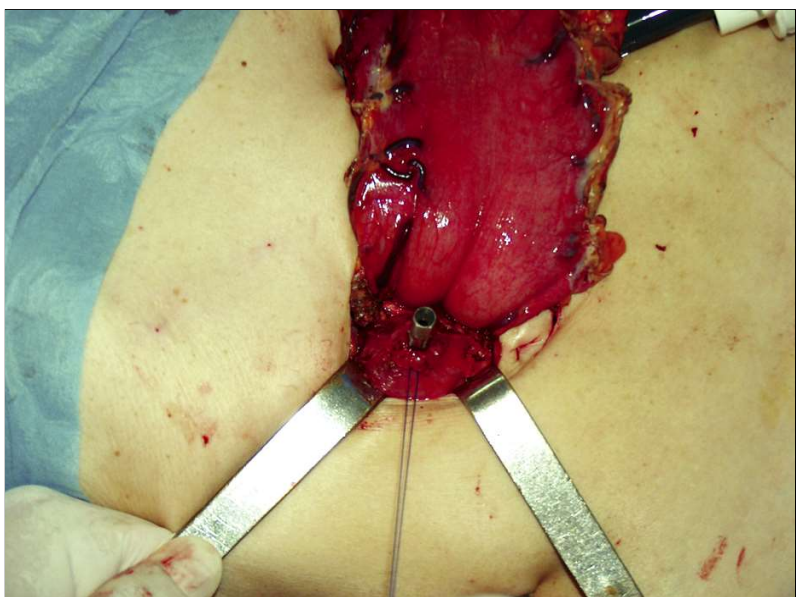

Figure 4. The anvil of a disposable circular stapler is placed in the duodenal stump and a purse string suture is tied over the anvil

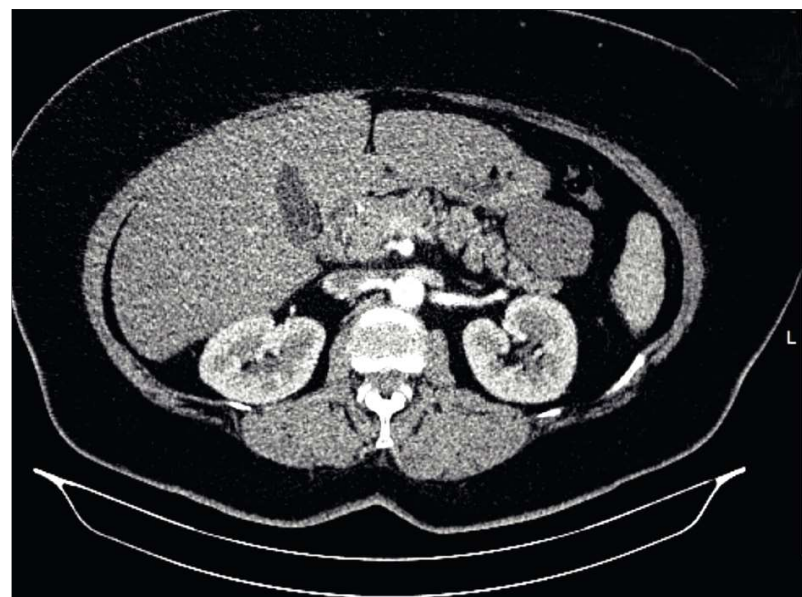

Figure 5. Axial CT image shows an extraluminal mass from the large curvature of stomach Endoscopic ultrasound (Fig 6) with guided fine needle aspiration (FNA) was performed in 8 cases and provided a positive diagnosis in 4 of them $(50 \%)$

of four gastric antrectomies and sixteen wedge gastric resections. In five cases robotic wedge gastrectomy was performed. The location of the tumour in cases performed by robotic approach was: gastroesophageal junction or cardia (3 cases), lesser curvature and posterior aspect of the body (1 case each). The difficult anatomical location of these cases prompted the use of the robotic approach over the laparoscopic one. One patient from the laparoscopic group was converted to open surgery due to adhesions from previous operation (low

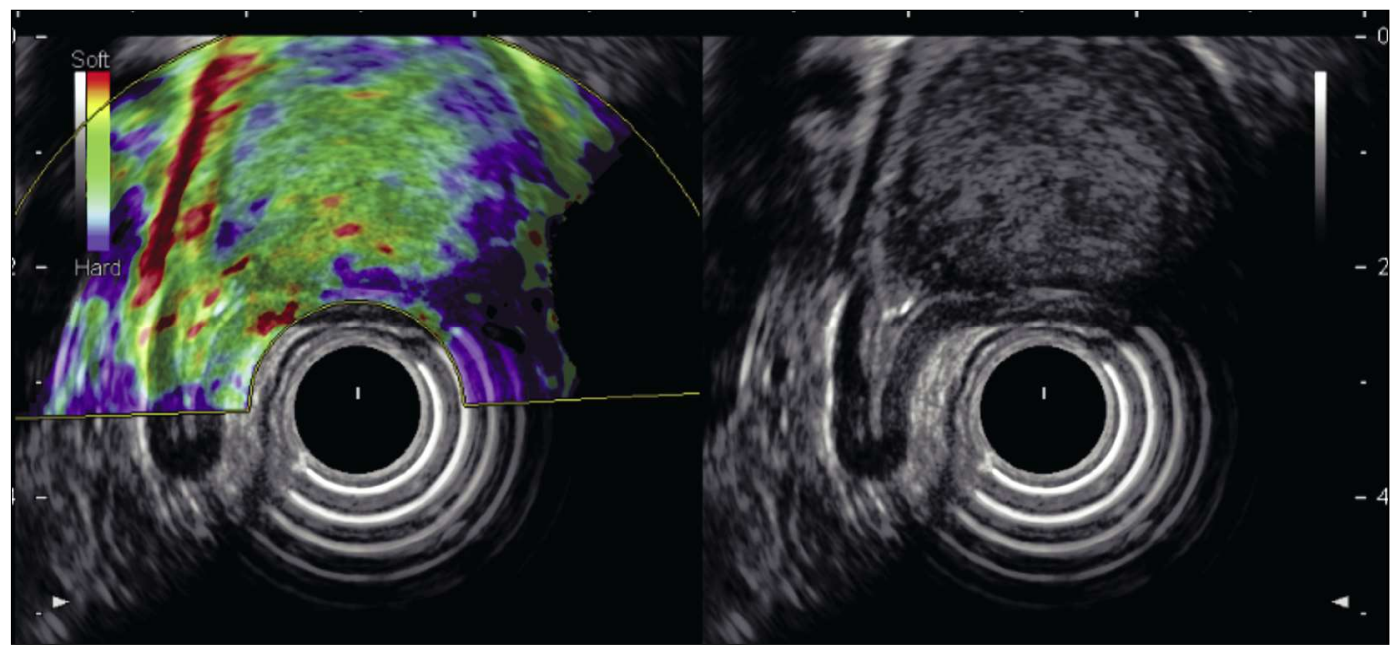

Figure 6. EUS shows a low-echoic antral lesion, $3.5 \mathrm{~cm}$ in diameter 
anterior resection for rectal cancer). The mean operative time was 130 minutes (range, 70210 minutes). There were no complications except one case that required reoperation for postoperative bleeding from the stapling line. The patient had been operated laparoscopically and the reintervention was performed via the open approach. There was no 90-day mortality recorded.

The mean tumour size was $3.8 \mathrm{~cm}$ (range, $2^{-}$ $7 \mathrm{~cm}) .22$ patients had tumours $<5 \mathrm{~cm}$ in largest diameter and had fewer than 5 mitoses per high-power field. The predominant histology type was the fusiform one in 24 patients (96\%), followed by the epithelioid type in one patient (4\%).

Immunohistochemistry analysis showed positive CD117 and CD34 on 23 patients (92\%). The final pathologic reports showed microscopically negative margins in all patients

The mean length of hospital stay was seven days (4-14).

\section{Discussion}

GISTs are the most common mesenchymal tumour originating in the gastrointestinal tract (11). The stomach is the most frequent location for GISTs, accounting for $50-70 \%$ of all cases (12). Historical studies6 have proven that although technically demanding, the laparoscopic approach to the surgical resection of gastric GISTs is safe and effective. The relatively recent advent of robotic surgery offers the possibility of expanding the indications for MAS resections of gastric GISTs situated in difficult anatomical locations, due to a less steep learning curve for the operating surgeon as well as crucial technical improvements.

The currently available literature offers a host of retrospective case control studies confirming overall superior short-term outcomes of laparoscopic versus open resection for gastric GISTs (faster recovery reflected in diminished length of hospital stay and decreased perioperative morbidity) (13).

The improvement in short term postoperative metrics brought about by MAS is compounded by the significantly improved quality of life reported by Dressler et al, which was found to be similar to otherwise healthy controls (14). In regards to the oncological safety for laparoscopic resection for gastric GISTs, small single centre retrospective (15) as well as propensity-score matched analyses seem to confirm the same results as the open approach (16). Nevertheless, larger multicentre prospective studies should confirm these promising results.

Lymphadenectomy and wide resections are not required in the surgical treatment of gastric GISTs, due to the fact that submucosal lymphatic spread does not occur in adult patients, as opposed to gastric adenocarcinoma. Therefore, gastric GISTs are ideal candidates for MAS in terms of the technical challenges faced by surgeons still on the learning curve (17).

The main limiting factor for the widespread use of laparoscopic techniques is the surgeon's expertise. In our Department only 10\% of the surgeons are performing advanced laparoscopic surgeries and another $10 \%$ are performing minimally invasive procedures, but are still on the learning curve. The adoption rate of laparoscopy in the treatment of gastric GISTs in our Department was $21.7 \%$ (another 90 resections for Gastric GIST were performed in the same period via an open approach).

The anatomical location of the tumour represents a key component in terms of choosing the appropriate surgical approach. Favourable locations consist of the greater curvature and anterior wall of the stomach, while all other regions of the stomach are considered unfavourable $(18,19)$. Gastric GISTs presenting in unfavourable anatomical locations (lesser curvature, posterior aspect, cardia, antrum) can prove challenging even for experienced laparoscopic surgeons.

Currently GISTs located at cardia and subcardial region are rarely treated with laparoscopy due to its technical limitations, e.g. the limited instrument range of motion and poor camera lens stability. Potentially these technical difficulties could be overcome by the robotic approach, as reported by Zhao et 
al (20). The rationale for this strategy is that currently available robotic operative systems possess a high-definition 3D field of view and a range of motion in seven directions, which significantly facilitates intracorporeal suturing in the cardial and subcardial regions (21). Most importantly, robotic surgical systems offer software eliminated tremor, making it more convenient to expose specific unfavourable anatomical sites $(9,22)$. The cases performed by robotic approach in our series were located in the following unfavourable locations: gastroesophageal junction or cardia, lesser curvature, and posterior aspect of the body.

Considering the fact that lymph node involvement is very rare in gastric GISTs, simple gastric wedge resections are used. However, employing this technique in the cardial and subcardial regions might lead to excessive gastric wall resection, which in turn causes postoperative complications such as stenosis (20).

Consequently, the combined use of laparoscopy and simultaneous gastroscopy for gastric GISTs resection was proposed, which presumably allows an enhanced approximation of the tumour boundary and the preservation of more normal gastric wall intraoperatively (23). Notwithstanding its advantages in small tumours, this technical innovation was however found to be timeconsuming (24).

In this context, the advantages of the robotic approach, i.e. its flexible operation arm and high-definition field of view, facilitate opening the gastric wall for accurate resection based on tumour boundary and complete suture in vivo intraoperatively, especially for gastric GISTs situated in unfavourable anatomical locations.

Nonetheless, it is crucial to point out that the gastric GIST anatomical site and the surgical approach do not seem to influence long-term outcomes (19). Moreover, Liao et al. (25), who compared the laparoscopic approach of gastric GIST in favourable vs unfavourable locations, found no significant difference in operative times, conversion rates, blood loss, tumour rupture rate, or postoperative morbidity between the two cohorts.

Perhaps a more serious risk in terms of oncological outcomes is posed by large $(>5 \mathrm{~cm})$ gastric GISTs, which are at higher risk of intraoperative rupture and spillage. The latter is associated with significantly higher recurrence rates as well as lower survival (12).

Nevertheless, a recent meta-analysis reported identical oncologic outcomes (disease free survival) in laparoscopic vs open resections for large $(>5 \mathrm{~cm})$ gastric GISTs (26). Given that the results of this meta-analysis demonstrated that laparoscopic resections were significantly associated with a shorter postoperative hospital stay and decreased blood loss, and that there were no statistically significant differences in the operation time or postoperative morbidity, MAS might be considered as the first option for uncomplicated gastric GISTs, regardless of their size.

In terms of overall short-term postoperative outcomes of laparoscopic vs open approach for gastric GISTs, recent meta-analyses have demonstrated the superiority of the former over the latter (shorter surgical times, decreased intraoperative blood loss, earlier time to flatus and an oral diet, and shorter hospital stays) (27, 28). Moreover, Ye et al demonstrated in their meta-analysis of laparoscopic vs open resections of gastric GISTs the same significant improvement of short-term postoperative results without compromising the long-term oncologicalrelated disease-free survival and overall survival (29).

The potential advantages of robotic surgery over the laparoscopic approach would comprise an expansion of indication of MAS for difficult anatomical locations due to a simplification of complex technical tasks such as intracorporeal suturing in less accessible locations (30). Nevertheless, large cohort studies validating these potential advantages are yet to be published in the context of a lack of widespread use of robotic resections of gastric GISTs due to an associated increase in operating time and potentially diminished cost-effectiveness.

It is noteworthy to emphasize the fact that 
most results to date regarding MAS resections in gastric GIST were derived from retrospective studies, which may render different conclusions due to confounding factors or selection bias.

\section{Conclusion}

The MAS approach of gastric GISTs is safe and effective and it is associated with lower morbidity compared to the open approach. Therefore, it should constitute the first option in patients with small tumours and favourable locations. In experienced hands, the indications for MAS resections of gastric GISTs may be safely expanded to large tumours $(>5 \mathrm{~cm})$ in unfavourable anatomical locations. Especially for subcardial and cardial gastric GISTs, the robotic approach may prove beneficial over the laparoscopic one due to the technical improvements it ushers in. The only limiting factor for the widespread use of MAS resections for gastric GISTs is surgeon expertise in this challenging technique.

\section{Author's Contributions}

Oana Stanciulea and Mihnea-Ioan Ionescu contributed equally to this work.

\section{Conflict of Interest}

The authors declare no conflicts of interests.

\section{References}

1. Nilsson B, Bümming $P$, Meis-Kindblom JM, Odén A, Dortok $A$, Gustavsson B, Sablinska K, Kindblom LG. Gastrointestinal stromal tumors: the incidence, prevalence, clinical course, and prognostication in the preimatinib mesylate era--a population-based study in western Sweden. Cancer. 2005;103(4):821-9.

2. Harlan LC, Eisenstein J, Russell MC, Stevens JL, Cardona K. Gastrointestinal stromal tumors: treatment patterns of a population-based sample. J Surg Oncol. 2015;111(6):702-7.

3. Søreide K, Sandvik OM, Søreide JA, Giljaca V, Jureckova A, Bulusu VR. Global epidemiology of gastrointestinal stromal tumours (GIST): A systematic review of population-based cohort studies. Cancer Epidemiol. 2016;40:39-46.

4. Joensuu H, Hohenberger P, Corless CL. Gastrointestinal stromal tumour. Lancet. 2013;382:973-983.

5. Fletcher CD, Berman JJ, Corless C, Gorstein F, Lasota J, Longley $\mathrm{BJ}$, et al. Diagnosis of gastrointestinal stromal tumors: A consensus approach. Hum Pathol. 2002;33(5):459-65.

6. Huguet KL, Rush RM Jr, Tessier DJ, Schlinkert RT, Hinder RA,
Grinberg GG, et al. Laparoscopic gastric gastrointestinal stromal tumor resection: the Mayo Clinic experience. Arch Surg. 2008; 143(6):587-90; discussion 591.

7. Zhao X, Yue C. Gastrointestinal stromal tumor. J Gastrointest Oncol. 2012;3(3):189-208.

8. Casali PG, Abecassis N, Aro HT, Bauer S, Biagini R, Bielack S, et al. ESMO Guidelines Committee and EURACAN. Gastrointestinal stromal tumours: ESMO-EURACAN Clinical Practice Guidelines for diagnosis, treatment and follow-up. Ann Oncol. 2018; 29(Supplement_4):iv267.

9. Tomulescu V, Stanciulea O, Balescu I, Vasile S, Tudor S, Gheorghe C, et al. First year experience of robotic-assisted laparoscopic surgery with 153 cases in a general surgery department: indications, technique and results. Chirurgia (Bucur). 2009;104(2):141-50.

10. Vasilescu C, Popescu I. Robotic surgery--possibilities and perspectives. Chirurgia (Bucur). 2008;103(1):9-11. Romanian

11. Arseneaux M, Yarbrough D, Nagamoto T. Robotic-assisted freehanded, full-thickness gastric GIST resection with primary repair in unfavorable locations. J Robot Surg. 2019;13(3):491-494.

12. Demetri GD, von Mehren M, Antonescu CR, et al. NCCN Task Force report: update on the management of patients with gastrointestinal stromal tumors. J Natl Compr Canc Netw 2010;8 Suppl 2:S1-41.

13. Koh YX, Goh BKP. Minimally invasive surgery for gastric gastrointestinal stromal tumors. Transl Gastroenterol Hepatol. 2017; 2:108. eCollection 2017.

14. Dressler JA, Palazzo F, Berger AC, Stake S, Chaudhary A, Chojnacki $\mathrm{KA}$, et al. Long-term functional outcomes of laparoscopic resection for gastric gastrointestinal stromal tumors. Surg Endosc. 2016; 30(4):1592-8. Epub 2015 Jul 14.

15. Honda M, Hiki N, Nunobe S, Ohashi M, Kiyokawa T, Sano T, et al. Long-term and surgical outcomes of laparoscopic surgery for gastric gastrointestinal stromal tumors. Surg Endosc. 2014;28(8): 2317-22.

16. Xu C, Chen T, Hu Y, Balde Al, Liu H, Yu J, et al. Retrospective study of laparoscopic versus open gastric resection for gastric gastrointestinal stromal tumors based on the propensity score matching method. Surg Endosc. 2017;31(1):374-381. Epub 2016 Jun 10.

17. DeMatteo RP, Lewis JJ, Leung D, Mudan SS, Woodruff JM, Brennan MF. Two hundred gastrointestinal stromal tumors: recurrence patterns and prognostic factors for survival. Ann Surg. 2000;231(1):51-8.

18. von Mehren M, Randall RL, Benjamin RS, Boles S, Bui MM, Casper ES, et al. Gastrointestinal stromal tumors, version 2.2014. J Natl Compr Canc Netw. 2014; 12(6):853-62.

19. Huang CM, Chen QF, Lin JX, Lin M, Zheng CH, Li P, et al. Can laparoscopic surgery be applied in gastric gastrointestinal stromal tumors located in unfavorable sites?: A study based on the NCCN guidelines. Medicine (Baltimore). 2017:96(14):e6535.

20. Zhao J, Wang G, Jiang Z, Jiang C, Liu J, Zhou J, Li J. Robotic Gastrotomy With Intracorporeal Suture for Patients With Gastric Gastrointestinal Stromal Tumors Located at Cardia and Subcardiac Region. Surg Laparosc Endosc Percutan Tech. 2018:28(1):e1-e7.

21. Diana M, Marescaux J. Robotic surgery. Br J Surg. 2015;102: e15-e28.

22. Vicente E, Quijano Y, Ielpo B, Duran H, Diaz E, Fabra I, et al. Robotassisted resection of gastrointestinal stromal tumors (GIST): a single center case series and literature review. Int J Med Robot. 2016;12(4):718-723. Epub 2015 Nov 9.

23. Mueller CL, Braun J, Leimanis ML, Mouhanna J, Feldman LS, Ferri $\mathrm{LE}$. Application of an individualized operative strategy for wedge resection of gastric gastrointestinal stromal tumors: Effectiveness for tumors in difficult locations. Surgery. 2016;160(4):1038-1048.

24. Komatsu S, Ichikawa D, Kosuga T, Okamoto K, Konishi H, Shiozaki A, et al. Clinical impact of laparoscopy and endoscopy cooperative surgery (LECS) on gastric submucosal tumor after its standardization. Anticancer Res. 2016;36:3041-3047.

25. Liao GQ, Chen T, Qi XL, Hu YF, Liu H, Yu J, et al. Laparoscopic 
management of gastric gastrointestinal stromal tumors: a retrospective 10-year single-center experience. World J Gastroenterol. 2017;23(19):3522-3529.

26. Cui JX, Gao YH, Xi HQ, Cai AZ, Zhang KC, Li JY, et al. Comparison between laparoscopic and open surgery for large gastrointestinal stromal tumors: A meta-analysis. World J Gastrointest Oncol. 2018;10(1):48-55

27. Zheng L, Ding W, Zhou D, Lu L, Yao L. Laparoscopic versus open resection for gastric gastrointestinal stromal tumors: a metaanalysis. Am Surg. 2014;80(1):48-56.

28. Chen QL, Pan Y, Cai JQ, Wu D, Chen K, Mou YP. Laparoscopic versus open resection for gastric gastrointestinal stromal tumors: an updated systematic review and meta-analysis. World J Surg Oncol. 2014;12:206

29. Ye L, Wu X, Wu T, Wu Q, Liu Z, Liu C, et al. Meta-analysis of laparoscopic vs. open resection of gastric gastrointestinal stromal tumors. PLoS One. 2017;12(5):e0177193. eCollection 2017.

30. de'Angelis N, Genova P, Amiot A, Charpy C, Disabato M, Belgaumkar AP, et al. Robotic Versus Laparoscopic Gastric Resection for Primary Gastrointestinal Stromal Tumors $>5 \mathrm{~cm}$ : A Size-Matched and Location-Matched Comparison. Surg Laparosc Endosc Percutan Tech. 2017;27(1):65-71. 